\title{
The value of remotely sensed vs. field-surveyed habitat structure for predicting bird abundance: a case study in traditional orchards
}

\author{
Laura Chaparro $^{1} \cdot$ Klaus Schmieder $^{1} \cdot$ Frank M. Schurr $^{1}$ (C) \\ Received: 5 July 2021 / Revised: 22 January 2022 / Accepted: 30 January 2022 / Published online: 20 February 2022 \\ (c) The Author(s) 2022
}

\begin{abstract}
Understanding environmental effects on the distribution and abundance of species is central to ecology, biogeography and evolutionary biology. This led to the development of species distribution models (SDMs) that relate spatial variation in occurrence and abundance to environmental variables. So far, SDMs rarely considered habitat structure, as a major determinant of bird distributions. While remote sensing increasingly provides high-resolution measures of habitat structure, certain structural variables affecting bird abundance still need to be measured with field surveys. In this study, we compare the value of remotely sensed vs. field-surveyed habitat structure for predicting bird abundance. Specifically, we analysed abundance data for nine bird species of traditional orchards in South-Western Germany. 'Remote sensing SDMs' related abundance to structural variables obtained by aerial photogrammetry of individual orchard trees. Alternative 'field survey SDMs' related bird abundance to detailed field surveys of the species composition and pruning state of orchard trees. Additionally, both remote sensing and field survey SDMs included climate and land use variables. Accounting for detailed habitat structure improved abundance predictions for seven of nine study species compared to models only incorporating climate and land use. The impact on model performance differed between remotely sensed and field-surveyed variables: the former improved abundance models for most $(n=7)$ bird species, whereas the latter had more variable impact, decreasing model performance for five species. The remotely sensed variable with strongest effects was overall tree density, which positively affected abundance of seven species. In contrast, multiple field-surveyed variables had similar effect strength, with the overall strongest effect found for pear tree density, to which seven bird species showed a unimodal response. These analyses have conservation implications since they predict expected responses of bird species to ongoing changes in orchard structure. Moreover, they identify structural variables that will be most promising to measure via remote sensing data in the future.
\end{abstract}

Keywords Biodiversity conservation $\cdot$ Fine-scale vegetation structure $\cdot$ Habitat structure $\cdot$ Population density $\cdot$ Remote sensing $\cdot$ Species distribution models

\section{Zusammenfassung}

Der Wert von Fernerkundungs- und Geländeerhebungen der Habitatstruktur für die Vorhersage von Vogelabundanzen: eine Fallstudie in Streuobstwiesen

Das Verständnis von Umwelteinflüssen auf die Verbreitung und Abundanz von Arten ist ein zentraler Forschungsgegenstand der Ökologie, Biogeographie und Evolutionsbiologie. Dies führte zur Entwicklung von Artverbreitungsmodellen (SDMs), die räumliche Variation in Verbreitung und Abundanz von Arten mit Umweltvariablen verknüpfen. Bislang bezogen SDMs jedoch nur selten die Habitatstruktur ein, obwohl diese einen wesentlichen Einfluss auf die Verbreitung von Vögeln hat. Während die Fernerkundung zunehmend hochaufgelöste Daten zur Habitatstruktur liefert, müssen bestimmte, für Vögel

Communicated by T. Gottschalk.

Laura Chaparro

laura_chaparro@outlook.com

1 Institute of Landscape and Plant Ecology, University of Hohenheim, Ottilie-Zeller-Weg 2, 70599 Stuttgart, Germany 
wichtige Strukturvariablen weiterhin durch Geländeerhebungen erfasst werden. Unsere Untersuchung vergleicht, wie gut Vogelabundanz durch Strukturvariablen vorhergesagt wird, die fernerkundlich bzw. im Gelände erfasst wurden. Hierzu wurden Abundanzdaten von neun Vogelarten der Streuobstwiesen Südwestdeutschlands analysiert. ,Fernerkundungsbasierte SDMs' verknüpften diese Abundanzdaten mit Strukturvariablen, die auf photogrammetrischen Analysen einzelner Streuobstbäume basieren. Alternative ,Gelände-SDMs 'verknüpften die Abundanzdaten mit Strukturvariablen aus Geländeerhebungen. Beide Modelle enthielten zusätzlich Klima- und Landnutzungsvariablen. Generell verbesserte die Berücksichtigung von detaillierten Strukturvariablen die Abundanzvorhersage für sieben der neun untersuchten Vogelarten im Vergleich zu Modellen, die lediglich Klima- und Landnutzungsvariablen enthalten. Fernerkundungs- und Geländevariablen unterschieden sich erheblich in ihrem Einfluss auf die Modellgüte. Fernerkundungsvariablen verbesserten die Modellgüte für den Großteil der untersuchten Vogelarten $(n=7)$, während Geländevariablen variableren Einfluss zeigten und die Modellgüte für fünf Arten sogar verringerten. Die Fernerkundungsvariable mit dem stärksten Effekt ist die Gesamtbaumdichte, die sich positiv auf die Abundanz von sieben Arten auswirkte. Im Gegensatz dazu hatten mehrere Geländevariablen ähnliche Effektstärken, wobei der stärkste Effekt für die Birnbaumdichte resultierte, auf die sieben Arten eine unimodale Reaktion zeigten. Unsere Modellanalysen haben Bedeutung für den Naturschutz, da sie erwartete Reaktionen von Vogelarten auf derzeitige Änderungen der Habitatstruktur von Streuobstwiesen vorhersagen. Darüber hinaus identifizieren sie diejenigen Strukturvariablen, deren zukünftige Erfassung durch Fernerkundung das größte Potenzial für ein verbessertes Verständnis von Vogelabundanzen hat.

\section{Introduction}

How the environment affects the geographical distribution and abundance of species is a central question in ecology, biogeography and evolutionary biology (Guisan and Thuiller 2005). Moreover, understanding which environmental variables limit distribution and abundance is of prime importance for predicting impacts of environmental change on biodiversity (Urban et al. 2016). Consequently, the past decades have seen an upsurge in species distribution models (SDMs) that statistically relate geographic data on the occurrence or abundance of species to environmental predictors.

Birds played a key role for the development and application of SDMs (Engler et al. 2017). However, many SDMs use only a restricted set of environmental variables. These are mostly climate and land use variables that are readily available from geographical databases (e.g. Barbet-Massin et al. 2012). While climate and land use have important effects on many bird species (Jetz et al. 2007), other environmental factors-notably fine-scale habitat structure-may be similarly important (Block and Brennan 1993).

Fine-scale habitat structure affects how birds forage, reproduce and escape from predators (MacArthur 1958; Chalfoun et al. 2002). Consequently, structural variables play a key role for habitat selection and for the distribution and abundance of birds (Cody 1981; Brokaw and Lent 1999). In the past, habitat structure has nevertheless rarely been included in avian SDMs, since it was difficult to measure at large spatial extents.

Substantial advances in remote sensing enable the mapping of fine-scale habitat structure at large spatial extents (He et al. 2015). For instance, satellite imagery can capture habitat heterogeneity and predict the distribution and diversity of birds across extensive regions (Gottschalk et al. 2005, 2007; Ozdemir et al. 2018; Farwell et al. 2020). Moreover, high-resolution photogrammetry or Light Detection and Ranging (LiDAR) enables the reconstruction of threedimensional vegetation structure and the automated measurement of variables, such as cover and height of woody vegetation or tree density. For instance, remotely sensed vegetation height has been shown to improve SDMs for the Golden-cheeked Warbler in Texas (Setophaga chrysoparia) (Farrell et al. 2013). Importantly, these remotely sensed variables can be recorded at large spatial extents and analyzed at different spatial scales (Meyer and Thuiller 2006; Seavy et al. 2009a, b). Remote sensing thus holds considerable promise for the development of 'next-generation SDMs' that represent aspects of habitat structure (He et al. 2015).

Not all bird-relevant aspects of habitat structure can currently be quantified through remote sensing. For instance, it remains a challenge to reliably identify plant species from remote sensing data. Yet the species composition of plant communities may determine the amount of resources available to birds and hence their distribution and abundance (Schmid et al. 2016a, b; Nottebrock et al. 2017). Moreover, small-scale human habitat management (pruning of trees, mowing of grasslands, etc.) is even more challenging to assess via remote sensing, even though it may have important impacts on birds and is thus commonly a focus of onthe-ground conservation (e.g. Magre et al. 2019). Structural variables that cannot be obtained from remote sensing typically need to be measured in labour- and cost-intensive field surveys, which severely limits the spatial extent over which these variables can be observed and hence their usefulness for SDMs. This raises the question of how valuable measures 
of habitat structure from remote sensing vs. field surveys are for understanding bird species distributions.

A suitable system for studying effects of habitat structure on bird distribution and abundance are traditional orchards. This agroforestry system consists of interspersed fruit trees growing on grassland and is found across Central Europe (Tojnko et al. 2011). Traditional orchards harbour a substantial diversity of vegetation structures and tree species. Moreover, they are a breeding habitat for bird species from both forests and semi open landscapes (Myczko et al. 2013). Consequently, traditional orchards are classified as a high nature value farming system at the European level (Cooper et al. 2007).

Traditional orchards experienced a decline in area of about $22 \%$ in Germany in a period of 40 years (Plieninger et al. 2015). In the state of Baden-Württemberg, which holds about $50 \%$ of Germany's traditional orchards, there was even a $60 \%$ loss of orchard trees in 50 years, from about 18 million trees in 1965 to around 7 million trees in 2015 (Borngräber et al. 2020). This loss of traditional orchards is mainly caused by the intensification of agriculture and urban expansion. Moreover, due to a lack of profitability, many orchards are either being abandoned (which leads to succession and an increase in woody plant cover) or dying trees are not replaced anymore so that tree density declines. To assess the impacts of these changes and to develop conservation strategies, it is important to understand the effect of vegetation structure on the distribution and abundance of birds in traditional orchards.

Here, we examine the impact of habitat structure on the abundance of nine bird species typical of traditional orchards. Specifically, we address four questions: (1) Can 'traditional SDMs' that only include climate and land use variables be improved by including information on habitat structure? (2) What is the relative value of habitat structure variables derived from remote sensing vs. field surveys? (3) Which aspects of habitat structure best explain variation in bird abundance? (4) How do different bird species respond to changes in the vegetation structure of traditional orchards?

\section{Methods}

\section{Study design}

We studied 120 plots of $1 \mathrm{~km}^{2}$ each that are spread throughout Baden-Württemberg and that are a subset of the test plots of the monitoring of frequent breeding birds by the Umbrella association of German avifaunists (DDA; Mitschke et al. 2005). For the analysis, each plot was subdivided into 100 subplots of 1 ha. At the subplot level, we then related birdspecies-specific abundance to variables describing habitat structure (obtained from either field surveys or remote sensing), land use and climate.

\section{Bird surveys}

Bird surveys were conducted as part of the monitoring of frequent breeding birds project coordinated by the Nature and Biodiversity Conservation Union (NABU) Baden-Württemberg for the State Institute for the Environment BadenWürttemberg (LUBW). The surveys were done by volunteer ornithologists who visited each plot four times a year, between March 10th and June 20th. In each visit, surveyors walked a ca. $3 \mathrm{~km}$ long line transect recording all birds to their front and sides (LUBW and NABU 2017). For this study, the monitoring data from 2006 to 2017 were analyzed. From the total list of birds found in the surveys, we selected nine species typical of traditional orchards (Table 1). The total number of individuals recorded per species and subplot was then divided by the total number of visits to obtain a measure of bird abundance that standardizes for differences in recording intensity.
Table 1 List of studied bird species giving their Red List status in Baden-Württemberg (Bauer et al. 2016), the total number of individuals recorded in the dataset and the number of 1 ha subplots in which the species was detected (out of a total of 543 subplots)

\begin{tabular}{llcc}
\hline Bird species & Red List status & $\begin{array}{c}\text { Number of } \\
\text { individuals }\end{array}$ & $\begin{array}{c}\text { Occupied } \\
\text { 1 ha sub- } \\
\text { plots }\end{array}$ \\
\hline Eurasian Wryneck (Jynx torquilla) & & 83 & 24 \\
Great Spotted Woodpecker (Dendrocopos major) & Least concern & 1885 & 118 \\
Grey-headed Woodpecker (Picus canus) & Endangered & 76 & 13 \\
Red-backed Shrike (Lanius collurio) & Least concern & 169 & 23 \\
Eurasian Nuthatch (Sitta europaea) & Least concern & 1721 & 107 \\
Short-toed Treecreeper (Certhia brachydactyla) & Least concern & 280 & 40 \\
Common Starling (Sturnus vulgaris) & Least concern & 4336 & 284 \\
Collared Flycatcher (Ficedula albicollis) & Vulnerable & 46 & 10 \\
Common Redstart (Phoenicurus phoenicurus) & Near threatened & 405 & 138 \\
\hline
\end{tabular}




\section{Remote sensing of habitat structure}

Remotely sensed habitat variables were obtained from photogrammetric analyses of aerial photographs taken between 2012 and 2015, as part of the LUBW project "Determination of the orchards of Baden-Württemberg using automated remote sensing methods" (Borngräber et al. 2020). These aerial photographs were taken during operational surveys of the State Geoinformation Agency (LGL) Baden-Württemberg at 3-year intervals frequency. To save storage space, the original spatial resolution of $23 \mathrm{~cm} /$ pixel was reduced to $40 \mathrm{~cm} /$ pixel. In a first step, 3D point clouds were extracted from the aerial photos and a digital surface model at a resolution of 6.25 points $/ \mathrm{m}^{2}$ was calculated using the software SURE (nFRAMES, Stuttgart, Germany). In a second step, a segmentation was performed by the software Workflow Engine for digital Surface Processing WESP (University of Hohenheim, Stuttgart, Germany; Borngräber et al. 2020) and different shape parameters were calculated for each segmented object (maximum height, length, width, area and perimeter). The third step included the classification of orchard trees based on these shape parameters. This objectbased classification of the photogrammetric data identified all trees in traditional orchards in Baden-Württemberg and quantified their individual canopy dimensions (Borngräber et al. 2020). We then aggregated these tree-level measures to calculate four remotely sensed structural variables at the subplot scale (see Table 2).

\section{Field surveys of habitat structure}

Field surveys in 2008 and 2018 recorded structural variables that cannot easily be obtained from remote sensing. Two of these field-recorded variables were the species identity and pruning state of all orchard trees in the study plots (Schmieder et al. 2011; Borngräber et al. 2020). These field-based measures were then aggregated at the subplot scale as described in Table 2. Comparison of the field surveys in 2008 and 2018 indicates that land use and orchard structure were relatively stable throughout the study period (Kassun 2018). On average, tree numbers in the study plots decreased by $0.8 \% / y e a r$, which amounts to a net loss of a single tree in most plots (Kassun 2018).

\section{Land use and climate variables}

Since bird abundance does not only depend on local habitat structure, all analyses comprised measures of climate and land use at the landscape scale. To account for climatic effects on bird abundance, we included long-term averages of spring temperature and precipitation (Worldclim, $30 \mathrm{~s}$ resolution; Fick and Hijmans 2017).

As land use variables (Table 3), we considered the area of legally protected habitats (biotope), areas with conservation status of the FFH mowing meadows (class), special protection areas (SPA), as well as four variables of land use and landscape composition: agricultural field, grassland, orchards and forest. These land use variables are not expected to have changed considerably during our study period.

\section{Data analysis}

We spatially restricted the data to the 543 subplots of 1 ha in which bird surveys were conducted (at least one bird record across all species) and field surveys of habitat structure registered at least one tree. Descriptive statistics for all structural, land use and climate variables can be found in the supplementary material (Online Appendix 1). Each studied bird species was analyzed separately using Linear Mixed-Effects Models fitted with Maximum Likelihood using the lme4 package (Bates et al. 2015) in R (Version 1.3.1093. R Core Team 2018). For each species, we fitted three alternative

Table 2 Variables describing habitat structure of traditional orchards measured by remote sensing and field surveys. All variables were calculated at the level of 1 ha subplots

\begin{tabular}{|c|c|c|}
\hline Method & Variable & Definition \\
\hline \multirow[t]{4}{*}{ Remote sensing } & Tree cover & Proportion of subplot area covered by tree canopies \\
\hline & Height heterogeneity & $\begin{array}{l}\text { Coefficient of variation of tree height per subplot, with values ranging between } 0 \text { (homoge- } \\
\text { neous height) and } 1 \text { (total heterogeneity in tree height) }\end{array}$ \\
\hline & Mean height & Mean tree height per subplot \\
\hline & Tree density & Number of trees per ha \\
\hline \multirow[t]{2}{*}{ Field surveys } & Density of different tree species & $\begin{array}{l}\text { Density of apple (Malus domestica), pear (Pyrus communis), cherry (genus Prunus avium.), } \\
\text { walnut (Juglans regia), plum (Prunus domestica); and other tree species (sorb (Sorbus } \\
\text { domestica), sweet chestnut (Castanea sativa), hazelnut (Corylus avellana) and quince } \\
\text { (Cydonia oblonga)), respectively }\end{array}$ \\
\hline & Pruning state & $\begin{array}{l}\text { Mean maintenance of trees, with individual trees classified as (1) regularly pruned, (2) } \\
\text { irregularly pruned, (3) not pruned }\end{array}$ \\
\hline
\end{tabular}


Table 3 Land-use variables included in the analysis of the two methods

\begin{tabular}{|c|c|c|c|}
\hline Variable & Type of data & Description & Source \\
\hline Biotope & Continuous & $\begin{array}{l}\text { Total area of legally protected habitats of field trees, } \\
\text { hedgerows and bushes located in the studied areas }\end{array}$ & $\begin{array}{l}\text { LUBW Data and Maps Service. Biotope nach } \\
\text { NatSchG und LWaldG.shp (LUBW 2020) }\end{array}$ \\
\hline Class & Factor & $\begin{array}{l}\text { Category of areas with conservation status of the } \\
\text { FFH mowing meadows: (A) excellent, (B) good } \\
\text { and (C) average (LUBW 2018); one last category } \\
\text { was included with the letter (K) for those areas that } \\
\text { are not within FHH-Mähwiesen classification }\end{array}$ & $\begin{array}{l}\text { Species and flower rich meadows according to the } \\
\text { EU Flora Fauna Habitat (FFH)_council directive } \\
\text { (Council Directive 92/43/EEC 1992). LUBW, } \\
\text { FFH-Mähwiesen.shp (LUBW 2018) }\end{array}$ \\
\hline SPA & Factor & $\begin{array}{l}\text { Classification of the plots considering if they are } \\
\text { inside a special protection area (SPA) according to } \\
\text { the EU Birds directive (Directive 2009/147/EG) }\end{array}$ & $\begin{array}{l}\text { LUBW data and maps service. Vogelschutzgebiete. } \\
\text { shp (LUBW 2018) }\end{array}$ \\
\hline $\begin{array}{l}\text { - Agricultural field } \\
\text { - Grassland } \\
\text { - Orchards } \\
\text { - Forest }\end{array}$ & Continuous & $\begin{array}{l}\text { Percentage of occupation of each category calculated } \\
\text { both within and in a } 2 \mathrm{~km} \text { buffer surrounding each } \\
\text { plot }\end{array}$ & $\begin{array}{l}\text { ATKIS-DLM (Official topographical and carto- } \\
\text { graphic information system-digital landscape } \\
\text { model, LGL 2015) }\end{array}$ \\
\hline
\end{tabular}

models: a 'base model' including only climate and land use variables (Biotope, class, SPA, landscape composition, temperature and precipitation), two models in which we additionally included structural variables derived either from remote sensing or field surveys (Tree cover, height heterogeneity, mean height and tree density; Density of different tree species and pruning state, respectively). In all models, bird abundance as the response variable $(\log x+0.1$ transformed) and the models included a random effect of plot identity. For all measures of habitat structure, we included both linear and quadratic terms, and all explanatory variables were centered and scaled. To quantify the explanatory value of characterizing habitat structure with either remote sensing or field surveys, we compared alternative models for the same species using the small sample size version of the Akaike Information Criterion (AICc as implemented in the MuMIn package; Barton 2019). To quantify the explanatory value of individual structural variables, we fitted a combined model that included climate, land use, remote sensing and field-surveyed variables. For each bird species and structural variable, we then calculated the partial $R^{2}$ as the reduction in marginal $R^{2}$ (Nakagawa et al. 2017) that results when removing the linear and quadratic effects of the variable from the combined model.

\section{Results}

\section{Accounting for habitat structure improves models of bird abundance}

Accounting for habitat structure improved models for the abundance of seven out of the nine study species (Table 4). The exceptions are the Red-backed Shrike and the Greyheaded Woodpecker whose densities were best explained by the 'base model' that only included climate and land use
Table 4 Comparison of alternative models for the nine studied bird species of traditional orchards by means of $\triangle \mathrm{AICc}$. The values presented in each column contain the true $\triangle \mathrm{AICc}$ of the respective model, meaning the difference from the best model which has $\triangle \mathrm{AICc}=0$

\begin{tabular}{llll}
\hline Species & \multicolumn{2}{l}{$\Delta \mathrm{AICc}$} & \\
\cline { 2 - 4 } & Base model & Remote sensing & Field surveys \\
\hline $\begin{array}{l}\text { Eurasian Wryneck } \\
\begin{array}{l}\text { Great Spotted Wood- } \\
\text { pecker }\end{array}\end{array}$ & 46.8 & 39.3 & 0.0 \\
$\begin{array}{l}\text { Grey-headed Wood- } \\
\text { pecker }\end{array}$ & 0.0 & 0.0 & 22.0 \\
$\begin{array}{l}\text { Red-backed Shrike } \\
\text { Eurasian Nuthatch }\end{array}$ & 0.0 & 13.6 & 20.4 \\
$\begin{array}{l}\text { Short-toed Treecreeper } \\
\text { Common Starling }\end{array}$ & 2.3 & 3.7 & \\
Collared Flycatcher & 50.2 & 0.0 & 19.6 \\
Common Redstart & 92.3 & 9.0 & 36.4 \\
\hline
\end{tabular}

variables. The model additionally including remotelysensed habitat structure was best for three species (Great Spotted Woodpecker, Eurasian Nuthatch and Short-toed Treecreeper), whereas the model including field-surveyed habitat structure performed best for four species (Eurasian Wryneck, Collared Flycatcher, Common Starling and Common Redstart; Table 4). However, for the Common Redstart the remote sensing model performed almost as good as the field survey model $(\triangle \mathrm{AICc}=5.7$, see Table 4$)$.

\section{The value of structural variables obtained by remote sensing and field surveys}

The inclusion of remotely sensed structural variables generally improved abundance models compared to the 'base model' (Fig. 1). Also, the remote sensing model was never the worst 


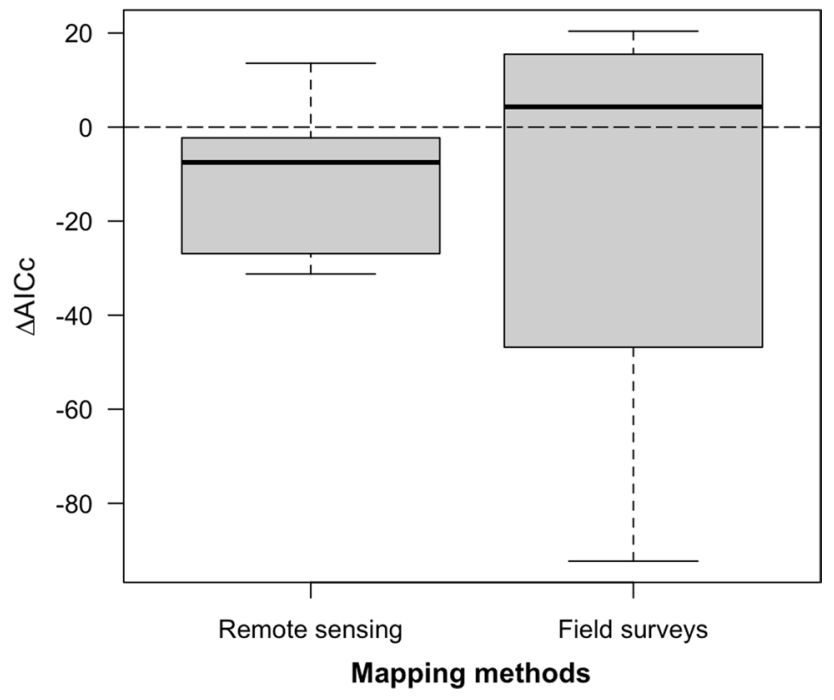

Fig. 1 The value of structural habitat variables derived by remote sensing or field surveys in models for the abundance of nine bird species of traditional orchards. The boxplot shows interspecific variation in the AICc difference that results when including the respective set of structural variables into a 'base model' which only contains climate and land use variables. A negative AICc difference indicates that inclusion of structural variables improves the model. For each box, the bold line represents the median, the bottom and top section of the box the 25th and 75th percentiles and the vertical dashed lines span the range of values (color figure online)

model for any of the nine study species (Table 4). In contrast, field-surveyed structural variables had more variable impact on model performance (Fig. 1) - their inclusion decreased model performance for five of the nine study species.

In general, the overall explanatory power (partial $R^{2}$ ) of structural variables was substantially higher than that of the climate variables and comparable to that of land use variables (Fig. 2; see Online Appendix 2 for marginal and conditional $R^{2}$ values). However, individual bird species differed more in the explanatory power of structural variables than in that of the other variable classes (Fig. 2). This large interspecific variance was particularly evident for field-surveyed structural variables (Fig. 2b).

The explanatory power (partial $R^{2}$ ) of individual structural variables in the combined model is reported in Fig. 3 and Online Appendix 3. Most variables had similar explanatory power but partial $R^{2}$ values tended to be highest for pear, walnut and plum density (Fig. 3). It should, however, be noted that the large number of parameters in the combined model caused the absolute values of partial $R^{2}$ to be small.

\section{Abundance responses of bird species to structural variables}

The effect strength of individual structural variables in the remote sensing and field survey models, respectively,

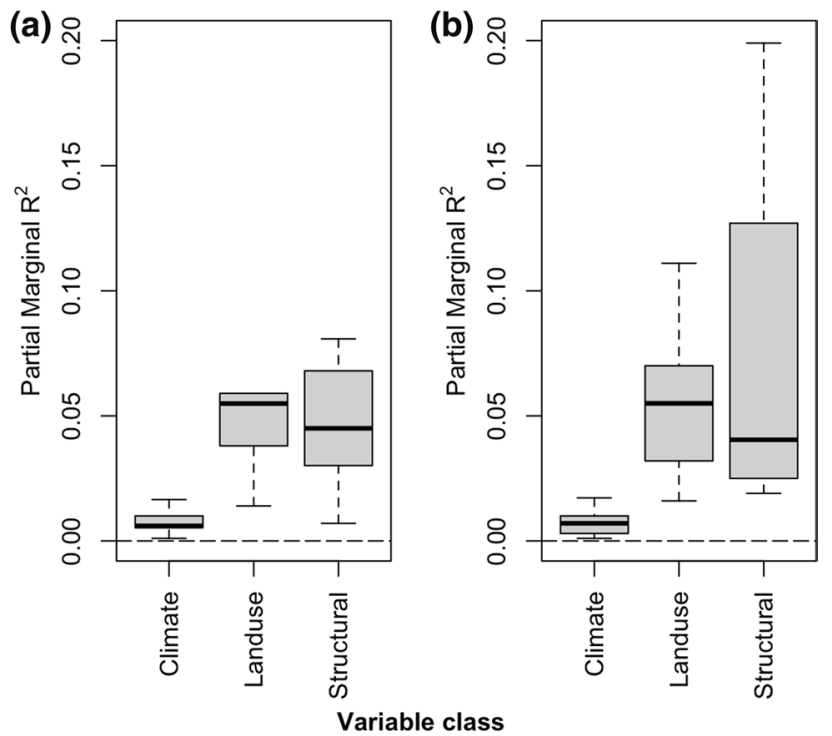

Fig. 2 Explanatory power of climate, land use and structural variables for the abundance of nine bird species of traditional orchards. Boxplots show the partial $R^{2}$ of each variable class in models using structural variables obtained by (a) remote sensing model, and (b) field surveys. For an explanation of boxplot components see Fig. 1 (color figure online)

is depicted in Fig. 4. Among the remotely sensed variables, tree density tended to have strongest effect on the abundance of the studied bird species (Fig. 4a). Within the group of field-surveyed variables, effect sizes were

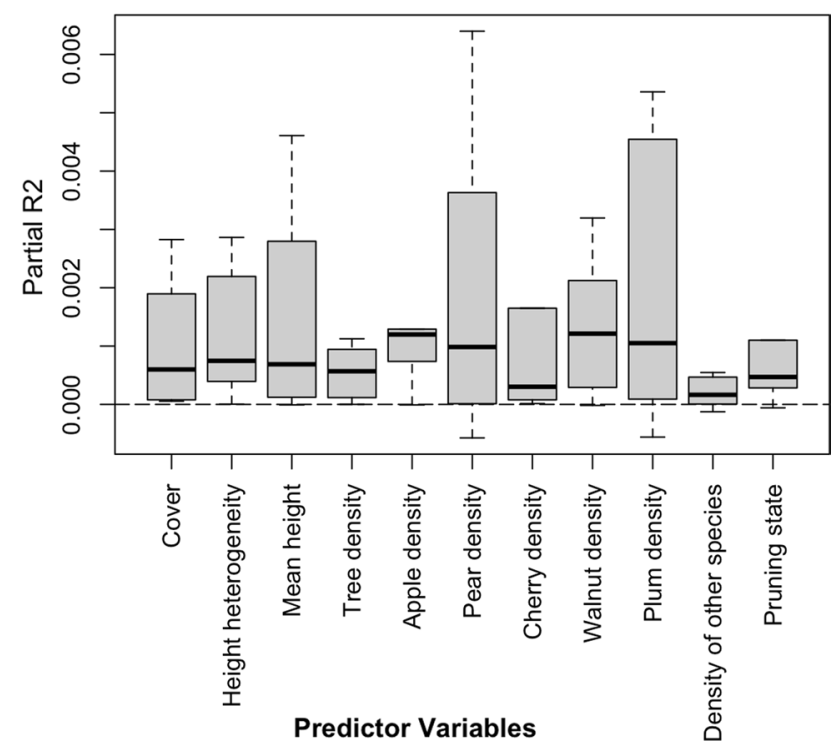

Fig. 3 Explanatory power of individual structural variables for the abundance of nine bird species of traditional orchards. Boxplots show the partial $R^{2}$ of each structural variable in a model combining structural variables obtained by remote sensing and field surveys. For an explanation of boxplot components see Fig. 1 (color figure online) 
Fig. 4 Effect strengths of structural variables on the abundance of nine bird species of traditional orchards. Boxplots show absolute standardized regression coefficients of both linear and quadratic terms for structural variables obtained by (a) remote sensing and (b) field surveys. For an explanation of boxplot components see Fig. 1 (color figure online)
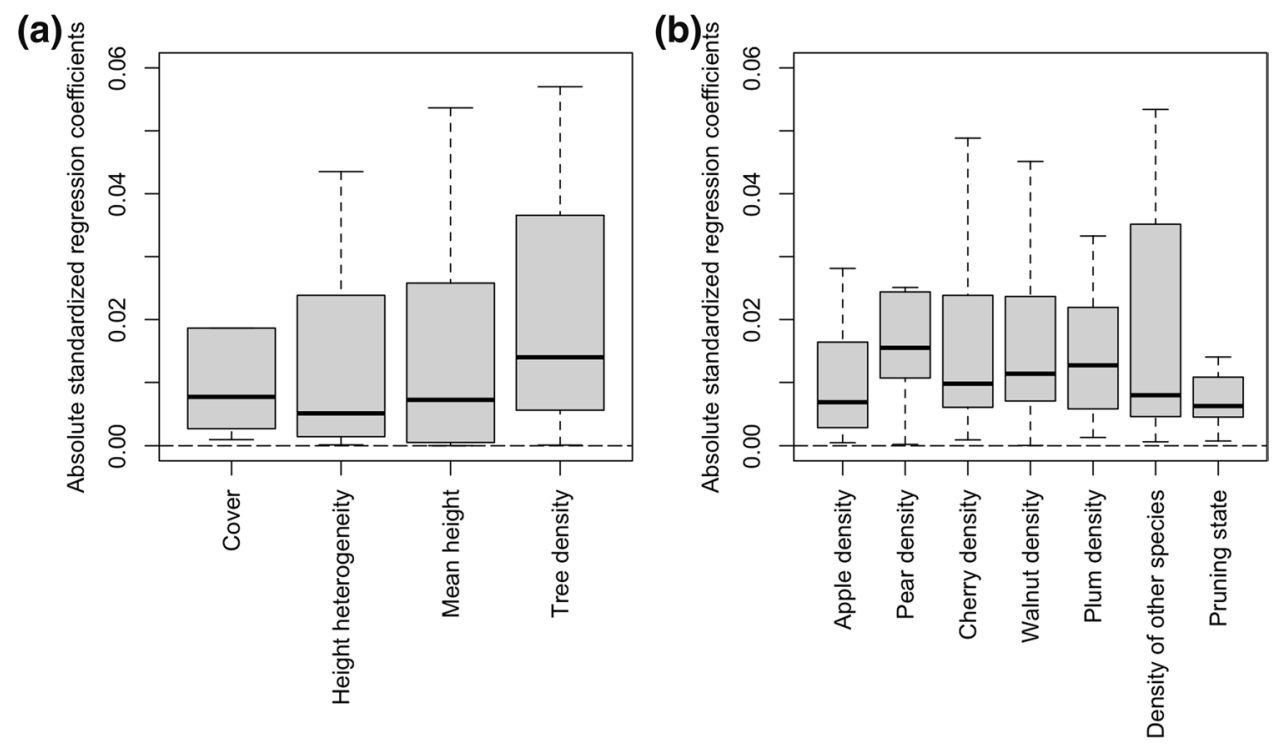

more similar, but the strongest interspecific median effects were detected for pear, cherry, walnut and plum density (Fig. 4b).

We evaluated the abundance response of each bird species to overall tree density and pear density as the structural variables with highest median effect strength among the remotely sensed and field-surveyed variables, respectively (Fig. 4). Overall tree density had generally positive effects on bird abundance (Fig. 5a). The only exceptions to this rule are the Red-backed Shrike and the Short-toed Treecreeper which showed unimodal responses to tree density peaking at 30 and 50 trees/ha, respectively (Fig. 5a). Such unimodal responses were more common for pear density, with seven species peaking at 2-5 pear trees/ha
(Fig. 5b). Only the Collared Flycatcher and the Common Redstart showed predominantly positive responses to pear density (Fig. 5b).

\section{Discussion}

We found that accounting for detailed information on habitat structure improved statistical models for the abundance of most studied bird species of traditional orchards (Fig. 1; Table 4). This structural information has explanatory power comparable to that of the considered land-use variables (Fig. 2). However, the impact on model performance differed between remotely sensed structural variables and variables

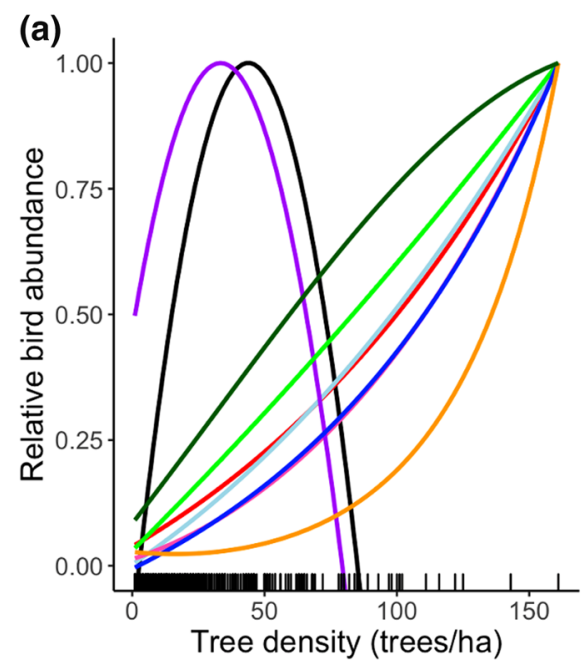

Fig. 5 Predicted abundance responses of nine bird species to variation in (a) remotely sensed overall tree density and (b) field-surveyed pear tree density. Predictions are scaled by the maximum predicted

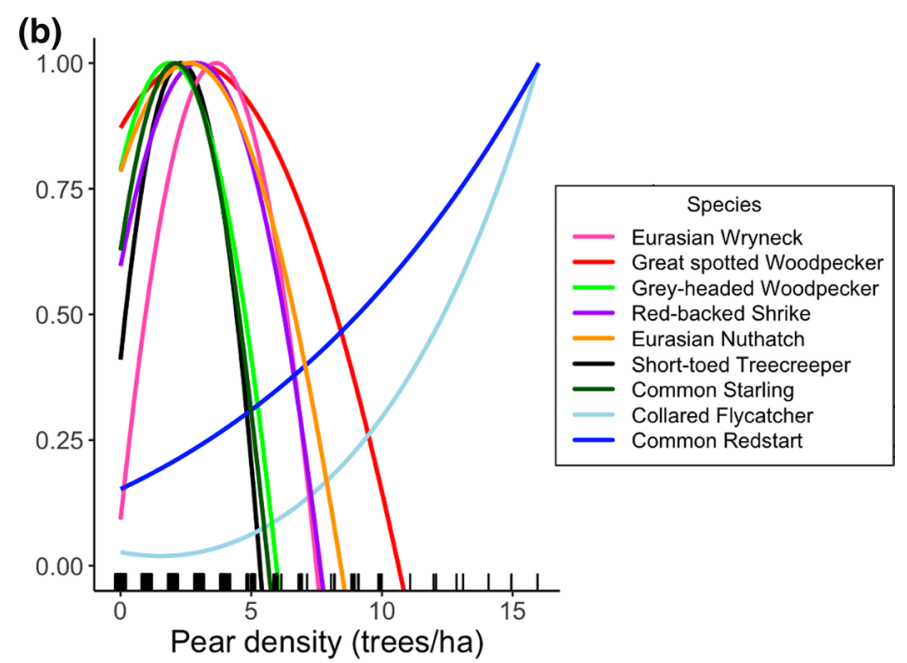

abundance for each species. Notches along the $\mathrm{x}$-axes represent the distribution of the structural variables (color figure online) 
that are currently only obtainable through field surveys: the former improved abundance models for most bird species whereas the latter had more variable impact (Fig. 1). Pear, walnut and plum density were the structural variables which tended to explain most of the variation in bird abundance (Fig. 3). The remotely sensed structural variable with strongest effects on the abundance of bird species was overall tree density (Fig. 4a), which increased the abundance of most bird species (Fig. 5a). Among the field-surveyed structural variables, multiple variables had similar effect strength, but the overall strongest effect (highest median) was found for the density of pear trees (Fig. 4b), to which most bird species showed a unimodal response (Fig. 5b). In the following, we discuss causes and conservations implications of the detected effects of orchard structure on birds, the value of remotely sensed versus field-surveyed habitat structure and perspectives for future research.

\section{Causes and conservations implications of detected effects of orchard structure on birds}

Overall tree density had a positive effect on seven of the nine studied bird species (Fig. 5a). This is expected given that trees provide nesting sites, increase the structural complexity of habitats, and increase resource availability for insectivorous and frugivorous animals (Manning et al. 2006). Moreover, trees improve bird movement, habitat connectivity and gene flow at the landscape level (Manning et al. 2006; Pizo and dos Santos 2011). Most study species should be negatively affected if land use intensification causes a reduction of tree density. On the other hand, vegetation succession on abandoned orchards will increase tree density and may thus initially benefit most bird species. However, the detected positive effects of tree density should not be extrapolated beyond the range of tree densities observed in this study (Fig. 5a). In fact, even species frequently found in forests (such as the Great Spotted Woodpecker or Eurasian Nuthatch) are likely to decline in abundance if tree density increases substantially beyond 150 trees/ha. Consequently, it is unlikely that most study species would persistently benefit from the abandonment of traditional orchards.

Pear tree density was among the structural variables with highest explanatory power (Fig. 3) and was the fieldsurveyed variable with strongest median effect across the study species (Fig. 4b). This might reflect the fact that pear trees dominate among the tallest and oldest trees in the studied orchards, and that their fissured bark and dense canopy harbour various insect species. On the other hand, pear trees tend to have less woodpecker and decay cavities than the apple trees dominating traditional orchards (Grüebler et al. 2013). Such opposing effects of pear trees on food and nesting site availability for different bird species may explain the species-specific but predominantly unimodal responses to pear density detected in this study (Fig. 5b). The density of tall pear trees is expected to decline both when traditional orchards are abandoned and when intensification causes tall trees to be replaced by lower-statured trees (mostly apple trees). Our results suggest that this decline will reduce the abundance of the Collared Flycatcher, Eurasian Wryneck and Common Redstart as three of the four study species that are red-listed in Baden-Württemberg (Bauer et al. 2016). In contrast, a decline of pear tree density may favour the Common Starlings on many sites (Fig. 5b).

\section{The value of remotely sensed versus field-surveyed measures of habitat structure}

Remotely sensed measures of habitat structure improved abundance predictions for seven of the nine study species, whereas field-surveyed measures were of less consistent importance (Fig. 1). Since we measured model performance by the AICc which penalizes for the number of parameters in a model, the poorer performance of the field survey model might in principle result from this model having more parameters than the remote sensing model. In this scenario, the effects of a few influential field-surveyed variables might get diluted by other field-surveyed variables of small effect. For the majority of study species, however, the partial $R^{2}$ (which is not penalized for the number of parameters) was not higher for field-surveyed compared to remotely sensed variables (Fig. 2). Moreover, different field-surveyed variables tended to have similar median effect strength (Fig. 4). Consequently, the more consistent effect of remotely sensed variables seems due to the fact that these variables capture major aspects of habitat structure that are relevant for most study species.

Field-surveyed measures of habitat structure nevertheless have important effects on the abundance of individual bird species. This is evident from fact that analyses including field-surveyed variables show large interspecific variability in AICc (Fig. 1), partial $R^{2}$ (Fig. 2), predictive power (Fig. 3) and effect size of individual variables (Fig. 4). Importantly, field-surveyed variables proved to be more informative than remotely sensed variables for three of the four red-listed study species (Collared Flycatcher, Eurasian Wryneck and Common Redstart; abundance of the fourth red-listed species, Grey-headed Woodpecker, did not show clear responses to any measures of habitat structure; Table 4). Since largescale field surveys of habitat structure are not feasible, this raises the question of how structural variables relevant for species of conservation concern can be collected at large spatial extents. 


\section{Research perspectives}

This study underlines the potential of remotely sensed habitat structure for explaining the distribution and abundance of birds (He et al. 2015). By identifying field-surveyed structural variables important for certain bird species, we also identify targets for future development in remote sensing. In particular, it would be valuable to remotely map key orchard tree species. In principle, remote sensing of hyperspectral, LIDAR and/or high-resolution photogrammetric data provides information that enables the identification of tree species (e.g. Kattenborn et al. 2019; Cao et al. 2020; James and Bradshaw 2020). Yet the remote identification of orchard tree species is relatively challenging since most of these species are closely related (belonging to the Rosaceae family) and thus phenotypically rather similar. The automated identification of orchard tree species thus still requires substantial efforts in the collection of ground-truthing data and the tuning of classification algorithms. Further promise lies in remote sensing of the spatiotemporal structure and management of the grass layer which provides important resources for orchard bird species. Important drivers of biodiversity loss in grasslands such as nitrogen deposition (Rockström et al. 2009; Maskell et al. 2010) can be estimated using remote sensing combined with modelling and monitoring (Zhang et al. 2021). While data on grassland structure and management are not yet available over large spatial extents, they can already be obtained at smaller extents via remote sensing with unmanned aerial vehicles (UAVs; Forsmoo et al. 2018). The availability of new structural variables covering large spatial extents should thus be a matter of time. Once reliable algorithms for predicting these variables are available, it will be possible to track changes in small-scale habitat structure at time intervals relevant for bird population dynamics. For instance, aerial photo surveys like the one used in this study (Borngräber et al. 2020) already cover the whole of Baden-Württemberg every three years.

It should thus become increasingly feasible to remotely sense habitat structure at the spatial and temporal resolution at which individual birds select territories, forage and reproduce (Buchmann et al. 2013; Schmid et al. 2016a, b). This opens new avenues for relating remotely sensed habitat structure not only to abundance and distribution but also to the demographic rates (e.g. reproduction and dispersal) that determine the dynamics of individual populations, species' geographical ranges and multi-species meta-communities (Kissling et al. 2012; Schurr et al. 2012; Pagel et al. 2020).

Supplementary Information The online version contains supplementary material available at https://doi.org/10.1007/s10336-022-01970-9.
Acknowledgements We would like to offer our sincerest gratitude to the Landesanstalt für Umwelt Baden-Württemberg LUBW, the Dachverband Deutscher Avifaunisten DDA and NABU Landesverband Baden-Württemberg for providing and sharing all the data and information of "Monitoring of frequent breeding birds by the Umbrella association of German avifaunists (DDA)" and "Traditional orchard survey Baden-Württemberg", which made this research possible. This research and the experiments comply with the current laws of the country in which they were performed.

Funding Open Access funding enabled and organized by Projekt DEAL.

Data availability The data that support the findings of this study are available from the Dachverband Deutscher Avifaunisten DDA but restrictions apply to the availability of these data, which were used under permission for the current study, and so are not publicly available. Data are however available from the authors upon reasonable request and with permission of the Dachverband Deutscher Avifaunisten DDA.

\section{Declarations}

Conflict of interest The authors have no conflicts of interest to declare that are relevant to the content of this article.

Open Access This article is licensed under a Creative Commons Attribution 4.0 International License, which permits use, sharing, adaptation, distribution and reproduction in any medium or format, as long as you give appropriate credit to the original author(s) and the source, provide a link to the Creative Commons licence, and indicate if changes were made. The images or other third party material in this article are included in the article's Creative Commons licence, unless indicated otherwise in a credit line to the material. If material is not included in the article's Creative Commons licence and your intended use is not permitted by statutory regulation or exceeds the permitted use, you will need to obtain permission directly from the copyright holder. To view a copy of this licence, visit http://creativecommons.org/licenses/by/4.0/.

\section{References}

Barbet-Massin M, Thuiller W, Jiguet F (2012) The fate of European breeding birds under climate, land-use and dispersal scenarios. Glob Change Biol 18:881-890

Barton K (2019) MuMIn: multi-model inference. R package version 1.43.6. https://CRAN.R-project.org/package=MuMIn. Accessed $13 \mathrm{Feb} 2020$

Bates D, Maechler M, Bolker B, Walker S (2015) Fitting linear mixedeffects models using lme4. J Stat Softw 67(1):1-48

Bauer H-G, Boschert M, Förschler MI, Hölzinger J, Kramer M, Mahler U (2016) Rote Liste und kommentiertes Verzeichnis der Brutvogelarten Baden-Württembergs. 6. Fassung. Stand 31. 12. 2013. - Naturschutz-Praxis Artenschutz 11

Block WM, Brennan LA (1993) The habitat concept in ornithology, theory and applications. Part of the current ornithology book series, vol 11. Springer, Boston

Borngräber S, Krismann A, Schmieder K (2020) Ermittlung der Streuobstbestände Baden-Württembergs durch automatisierte Fernerkundungsverfahren. Naturschutz und Landschaftspflege Baden-Württemberg 81:17 
Brokaw N, Lent R (1999) Vertical structure. In: Hunter M (ed) Maintaining biodiversity in forest ecosystems. Cambridge University Press, Cambridge, pp 373-399

Buchmann C, Schurr F, Nathan R, Jeltsch F (2013) Habitat loss and fragmentation affecting mammal and bird communities-the role of interspecific competition and individual space use. Eco Inform 14:90-98

Cao K, Zhang X (2020) An improved res-UNet model for tree species classification using airborne high-resolution images. Remote Sens 12:1128

Chalfoun AD, Thompson FR, Ratnaswamy MJ (2002) Nest predators and fragmentation: a review and meta-analysis. Conserv Biol 16:306-318

Cody M (1981) Habitat selection in birds: the roles of vegetation structure, competitors, and productivity. Bioscience 31(2):107-113

Cooper T, Arblaster K, Baldock D, Farmer M, Beaufoy G, Jones G, Poux X, McCracken D, Bignal E, Elbersen B, Wascher D, Angelstam P, Roberge J, Pointereau P, Seffer J, Galvanek D (2007) Final report for the study on HNV indicators for evaluation. Institute for European Environmental Policy, London, p 35

Council Directive 92/43/EEC (1992) On the conservation of natural habitats and of wild fauna and flora. From https://eur-lex.europa. eu/legal-content/EN/TXT/?uri=CELEX:31992L0043. Accessed 16 July 2019

Engler JO, Stiels D, Schidelko K, Strubbe D, Quillfeldt P, Brambilla M (2017) Avian SDMs: current state, challenges, and opportunities. J Avian Biol 48:1483-1504

Farrell SL, Collier BA, Skow KL, Long AM, Campomizzi AJ, Morrison ML, Hays KB, Wilkins RN (2013) Using LiDAR-derived vegetation metrics for high-resolution, species distribution models for conservation planning. Ecosphere 4:art42

Farwell LS, Elsen PR, Razenkova E, Pidgeon AM, Radeloff VC (2020) Habitat heterogeneity captured by $30-\mathrm{m}$ resolution satellite image texture predicts bird richness across the United States. Ecol Appl 30(8): 02157

Fick SE, Hijmans RJ (2017) WorldClim 2: new 1 km spatial resolution climate surfaces for global land areas. Int J Climatol 37(12):4302-4315

Forsmoo J, Anderson K, Macleod CJA, Wilkinson ME, Brazier R (2018) Drone-based structure-from-motion photogrammetry captures grassland sward height variability. J Appl Ecol 00:2587-2599

Gottschalk TK, Huettmann F, Ehlers M (2005) Thirty years of analysing and modelling avian habitat relationships using satellite imagery data: a review. Int J Remote Sens 26:2631-2656

Gottschalk TK, Ekschmitt K, Bairlein F (2007) A GIS-based model of Serengeti grassland bird species. Ostrich 78(2):259-263

Grüebler MU, Schaller S, Keil H, Naef-Denzer B (2013) The occurrence of cavities in fruit trees: effects of tree age and management on biodiversity in traditional European orchards. Biodivers Conserv 22:3233-3246

Guisan A, Thuiller W (2005) Predicting species distribution: offering more than simple habitat models. Ecol Lett 8:993-1009

He KS, Bradley BA, Cord AF, Rocchini D, Tuanmu M-N, Schmidtlein S, Turner W, Wegmann M, Pettorelli N (2015) Will remote sensing shape the next generation of species distribution models? Remote Sens Ecol Conserv 1:4-18

James K, Bradshaw K (2020) Detecting plant species in the field with deep learning and drone technology. Methods Ecol Evol 11:1509-1519

Jetz W, Wilcove DS, Dobson AP (2007) Projected impacts of climate and land-use change on the global diversity of birds. PLoS Biol $5: 157$

Kassun B (2018) Stand comparison of traditional orchards in BadenWürttemberg 2008 and 2018. MSc Thesis University of Hohenheim. pp 213
Kattenborn T, Eichel J, Fassnacht FE (2019) Convolutional Neural Networks enable efficient, accurate and fine-grained segmentation of plant species and communities from high-resolution UAV imagery. Sci Rep 9:17656

Kissling WD, Dormann CF, Groeneveld J, Hickler T, Kühn I, McInerny G, Montoya JM, Römermann C, Schiffers K, Schurr FM, Singer A, Svenning J-C, Zimmermann NE, O'Hara RB (2012) Novel approaches to modelling biotic interactions in multispecies assemblages at broad spatial scales. J Biogeogr 39:2163-2178

LGL (2015) Landesamt für Geoinformation und Landentwicklung Baden-Württemberg: Digitale ATKIS-DLM Datensätze. Retrieved from https://www.lgl-bw.de. 13 Feb 2020

LUBW (2018) Ergänzung zu den Kartieranleitungen für die beiden Lebensraumtypen 6510 Magere Flachland-Mähwiesen und 6520 Berg-Mähwiesen, Anhang XIV. InsVV, (April), 470-476. From https://pudi.lubw.de/detailseite?p_p_id=de_xdot_lubw_pudi_ frontend_web_portlet_DetailPortlet\&p_p_lifecycle $=2 \&$ p_p_ state $=$ normal\&p_p_mode $=$ view $\&$ p_p_resource_id $=\% 2 \mathrm{Fapp}$ endix \%2Fdownload\&p_p_cacheability =cacheLevelPage\&_de_ xdot_lubw_pudi_frontend_web_portlet_DetailPortlet_appen dixId=a1c6fbe184394ab49ca0c2dec5a129bf\&_de_xdot_lubw_ pudi_frontend_web_portlet_DetailPortlet_pudiId=69643\&_de_ xdot_lubw_pudi_frontend_web_portlet_DetailPortlet_pudiId= 69643. Accessed 16 July 2019

LUBW (2020) Daten- und Kartendienst der LUBW Landesanstalt für Umwelt Baden-Württemberg. Retrieved from https://udo.lubw. baden-wuerttemberg.de/public/_13 Feb 2020

LUBW and NABU (Landesanstalt für Umwelt Baden-Württemberg and Naturschutzbund Deutschland Landesverband Baden-Württemberg) (2017) Monitoring häufiger Brutvögel, Kartierungsanleitung 2017. From https://www.lubw.baden-wuerttemberg. de/documents/10184/213235/Anlage+4_MhB_BW_Kartierung sanleitung_2017.pdf/a08329c7-ad7f-42f9-8784-b093e54424ac. Accessed 20 June 2019

MacArthur RH (1958) Population ecology of some warblers of northeastern coniferous forests. Ecology 39:599-619

Magre J, Boada JM, Campanera JM, Bach Pagès A, Ruiz MI, Maneja ZR, Sánchez MS, Pallarès BM, Barriocanal LC (2019) How urban green management is influencing passerine birds' nesting in the Mediterranean: a case study in a Catalan city. Urban for Urban Green 41:221-229

Manning AD, Fischer J, Lindenmayer DB (2006) Scattered trees are keystone structures, implications for conservation. Biol Cons 132:311-321

Maskell LC, Smart SM, Bullock JM, Thompson K, Stevens CJ (2010) Nitrogen deposition causes widespread loss of species richness in British habitats. Glob Change Biol 16:671-679

Meyer CB, Thuiller W (2006) Accuracy of resource selection functions across spatial scales. Divers Distrib 12:288-297

Mitschke A, Sudfeldt C, Heidrich-Riske H, Dröschmeister R (2005) Das neue Brutvogelmonitoring in der Normallandschaft Deutschlands - Untersuchungsgebiete, Erfassungsmethode und erste Ergebnisse. Vogelwelt 126:127-140

Myczko Ł, Rosin ZM, Skórka P, Wylegała P, Tobolka M, Fliszkiewicz M, Mizera T, Tryjanowski P (2013) Effects of management intensity and orchard features on bird communities in winter. Ecol Res 28:503-512

Nakagawa S, Johnson PCD, Schielzeth H (2017) The coefficient of determination $R^{2}$ and intra-class correlation coefficient from generalized linear mixed-effects models revisited and expanded. J R Soc Interface 14:20170213

Nottebrock H, Schmid B, Mayer K, Devaux C, Esler KJ, BöhningGaese K, Schleuning M, Pagel J, Schurr FM (2017) Sugar landscapes and pollinator-mediated interactions in plant communities. Ecography 40:1129-1138 
Ozdemir I, Mert A, Ozkan UY, Aksan S, Unal Y (2018) Predicting bird species richness and micro-habitat diversity using satellite data. For Ecol Manage 424:483-493

Pagel J, Treurnicht M, Bond WJ, Kraaij T, Nottebrock H, Schutte-Vlok A, Tonnabel J, Esler KJ, Schurr FM (2020) Mismatches between demographic niches and geographic distributions are strongest in poorly dispersed and highly persistent plant species. PNAS 117:3663-3669

Pizo MA, dos Santos BTP (2011) Frugivory, post-feeding flights of frugivorous birds and the movement of seeds in a Brazilian fragmented landscape. Biotropica 43:335-342

Plieninger T, Levers C, Mantel M, Costa A, Schaich H, Kuemmerle T (2015) Patterns and drivers of scattered tree loss in agricultural landscapes: orchard meadows in Germany (1968-2009). PLoS ONE 10(5): 0126178

R Core Team (2018) R: a language and environment for statistical computing. R Foundation for Statistical Computing, Vienna, Austria. URL https://www.R-project.org/. Accessed 20 June 2019

Rockström J, Steffen W, Noone K, Persson A, Chapin FS, Lambin EF, Lenton TM, Scheffer M, Folke C, Schellnhuber HJ, Nykvist B, de Wit CA, Hughes T, Leeuw S, Rodhe H, Sörlin S, Snyder PK, Costanza R, Svedin U, Falkenmark M, Karlberg L, Corell RW, Fabry VJ, Hansen J, Walker B, Liverman D, Richardson K, Crutzen P, Foley JA (2009) A safe operating space for humanity. Nature 461:472-475

Schmid B, Nottebrock H, Esler KJE, Pagel J, Böhning-Gaese K, Schurr FM, Mueller T, Schleuning M (2016a) A bird pollinator shows positive frequency-dependence and constancy of species choice in natural plant communities. Ecology 97:3110-3118

Schmid B, Nottebrock H, Esler KJ, Pagel J, Pauw A, Böhning-Gaese K, Schurr FM, Schleuning M (2016b) Responses of nectar-feeding birds to floral resources at multiple spatial scales. Ecography 39:619-629
Schmieder K, Krismann A, Balko J, Küpfer C (2011) Die Streuobsterhebung Baden-Württemberg 2009. Berichte des Instituts für Landschafts- und Pflanzenökologie Universität Hohenheim. Beiheft 26:31-46

Schurr FM, Pagel J, Cabral JS, Groeneveld J, Bykova O, O'Hara RB, Hartig F, Kissling WD, Linder HP, Midgley GF, Schröder B, Singer A, Zimmermann NE (2012) How to understand species' niches and range dynamics: a demographic research agenda for biogeography. J Biogeogr 39:2146-2162

Seavy NE, Viers JH, Wood JK (2009a) Riparian bird response to vegetation structure: a multiscale analysis using LiDAR measurements of canopy height. Ecol Appl 19:1848-1857

Seavy NE, Viers JH, Wood JK (2009b) Riparian bird response to vegetation structure: a multiscale analysis using LiDAR measurements of canopy height. Ecol Appl 19(7):1848-1857

Tojnko S, Rozman Č, Unuk T, Pažek K, Pamič S (2011) A qualitative multi-attribute model for the multifunctional assessment of "Streuobst Stands" in NE Slovenia. Erwerbs-Obstbau 53:157-166

Urban J (2016) Are we measuring concern about global climate change correctly? Testing a novel measurement approach with the data from 28 countries. Clim Change 139:397-411

Zhang Q, Li Y, Wang M, Wang K, Meng F, Liu L, Zhao Y, Ma L, Zhu Q, Xu W, Zhang F (2021) Atmospheric nitrogen deposition: a review of quantification methods and its spatial pattern derived from the global monitoring networks. Ecotoxicol Environ Safety $216: 112180$

Publisher's Note Springer Nature remains neutral with regard to jurisdictional claims in published maps and institutional affiliations. 